\title{
Nitrate Content in Potatoes Cultivated in Contaminated Groundwater Areas
}

\author{
Alenka Hmelak Gorenjak ${ }^{1}$, Davorin Urih ${ }^{1}$, Tomaž Langerholc ${ }^{1} \&$ Janja Kristl ${ }^{1}$ \\ ${ }^{1}$ Faculty of Agriculture and Life Sciences, University of Maribor, Maribor, Slovenia \\ Correspondence: Alenka Hmelak Gorenjak, Faculty of Agriculture and Life Sciences, University of Maribor, \\ Maribor, Slovenia. Tel: 386-2320-9042. E-mail: alenka_hg@yahoo.com
}

Received: October 11, 2013 Accepted: November 18, 2013 Online Published: November 25, 2013

doi:10.5539/jfr.v3n1p18

URL: http://dx.doi.org/10.5539/jfr.v3n1p18

\begin{abstract}
For a number of years Dravsko polje plain has been subject to intensive farming. Consequently, groundwater in this area is heavily contaminated with nitrates and pesticides. The goal of the study was to determine the quality of potatoes, based on nitrate levels cultivated in an area of contaminated groundwater. We also examined the influence of sustainable agriculture on the quality of crops. Nitrate content was determined using RP/HPLC/UV chromatography. Average nitrate content in potatoes cultivated on Dravsko polje plain was $157 \mathrm{mg} / \mathrm{kg}$ (range $18-429 \mathrm{mg} / \mathrm{kg}$ ), which was not significantly different from the nitrate content in potatoes cultivated outside the contaminated area (mean value $145 \mathrm{mg} / \mathrm{kg}$; range $28-448 \mathrm{mg} / \mathrm{kg}$ ). In $18 \%$ of all samples, nitrate content exceeded maximum recommended levels. In potatoes cultivated via integrated production nitrate content did not significantly differ from the one in conventionally cultivated potatoes. In contrast, organic potatoes contained lower levels of nitrates (range 14-156 mg/kg). Our results also show that individual potato varieties are characterized by different trends of nitrate accumulation. Strict adherence to sustainable agriculture is reflected in lower levels of nitrate in potatoes.
\end{abstract}

Keywords: potatoes, nitrate, HPLC chromatography, contaminated groundwater, production system, variety

\section{Introduction}

Potato is an important and popular food in the European Union [EU] as it is by consuming quantities in the second place, behind wheat. The highest consumption per person per year is in Latvia - $178 \mathrm{~kg}$, while in Poland it is $118 \mathrm{~kg}$ and in Greece $103 \mathrm{~kg}$. In Slovenia, the consumption of $84 \mathrm{~kg}$ of potatoes per person per year is above the European average of $73 \mathrm{~kg}$ (Eurostat, 2011). Potatoes are not only an important source of energy, but also contain a number of micronutrients, such as vitamin $\mathrm{C}$ and some forms of vitamin B, potassium, magnesium, iron, and zinc (Weichselbaum, 2010). Depending on dietary habits, potatoes can be the main source of nitrate intake. Namely, vegetables account for $97 \%$ of our nitrate intake, of which $32 \%$ originates from potato consumption and 29\% from lettuce consumption (Santamaria, 2006; Thomson, Nokes, \& Cressey, 2007).

The factors leading to the difference of nitrate contents in different vegetables are complex and a number of studies on the mechanism of nitrate accumulation have been done, mainly on the nitrate uptake rate, nitrate reductase activity, and growth rate, which are closely related to carbon metabolism. Besides the genetic factor, growth conditions also play a decisive role in the nitrate accumulation of plants: nitrogen fertilizers, variety and crop protection strategies, soil moisture, light intensity and temperature (Hmelak Gorenjak, \& Cencič, 2013). However, the fundamental factor of nitrate content in vegetables should be the imbalance between nitrate uptake and reduction (Du, Zhang, \& Lin, 2007).

Nitrate per se is relatively non-toxic (Speijers, 1996), however by the action of natural bacterial flora in the buccal cavity approx. $4-7 \%$ of the nitrate intake is reduced to more toxic nitrite (McKnight, Smith, Drummond, Duncan, Goldem, \& Benjamin, 1997). In the acidic environment of the stomach, nitrite is converted to nitric acid and other N-nitroso compounds, which may react with secondary amines to form cancerogenic nitrosamines (Walker, 1990). A well-known adverse effect of nitrate to human organism is the binding of nitrite to haemoglobin, resulting in formation of methaemoglobin (Walker, 1990; Santamaria, 2006; Lundberg, Weitzberg, \& Gladwin, 2008; Hmelak \& Cencič, 2013).

The acceptable daily intake [ADI] of nitrate is allocated as $0-0.37 \mathrm{mg} / \mathrm{kg}$ body weight and for nitrite as $0-0.07$ 
$\mathrm{mg} / \mathrm{kg}$ body weight. Exceeding the ADI limits for nitrate and nitrite occurs frequently in daily human life (Santamaria, 2006; Hord, Tang, \& Bryan, 2009; Sobko, Marcus, Govoni, \& Kamiya, 2010; Hmelak Gorenjak, Rižman, \& Cencič, 2012). The EU established different limits for nitrate concentration in spinach, lettuce and rucola, depending on the season of cultivation. Higher levels of nitrate are permitted for products grown in winter than in summer according European Commission [EC] No. 1258/2011 (EC, 2011). To date, no official limits for nitrate content of potato have been set by the $\mathrm{EU}$, although several countries have proposed their own guidelines. In Germany, only tubers with less than $200 \mathrm{mg} \mathrm{NO} / \mathrm{kg}$ fresh weight are accepted (Santamaria, 2006) and in Poland the maximum limit is $183 \mathrm{mg} \mathrm{NO}_{3} / \mathrm{kg}$ fresh weight (Cieślik \& Sikora, 1998).

There are several areas in Slovenia where, due to intensive agriculture, the groundwater is polluted with nitrates. Among the heavily polluted areas is the groundwater of Dravsko polje plain, which is most polluted in its central part. Agri-environmental problems in this area stem from intensive fodder crop production. Furthermore, the groundwater is a major source of drinking water, which poses considerable problems for human health. The Environmental Protection Agency [EPA] set the Maximum Contaminant Level [MCL] for groundwater at $10 \mathrm{mg}$ $\mathrm{NO}_{3}-\mathrm{N} / \mathrm{L}$ or $45 \mathrm{mg} \mathrm{NO}_{3} / \mathrm{L}$ (EPA, 2012), while the Slovenian legislation set the MCL at $50 \mathrm{mg} \mathrm{NO} / \mathrm{L}$ (Official Gazette RS [UL RS], 2009). The Slovenian Environment Agency has been monitoring the groundwater of Dravsko polje plain since 1987. The latest results showed that at several sites, nitrate and pesticide concentrations exceeded maximum permitted levels (Gacin, Mihorko, Dobnikar, \& Knez, 2012). It is no coincidence that in 1998, a national research and development project was set up in order to introduce integrated vegetable production to this region. Sustainable production was introduced in 2002 (Bavec, Grobelnik, Rozman, Pažek, \& Bavec, 2009).

Consumers are often suspicious of crops cultivated in agricultural intensive areas such as Dravsko polje plain. In this area the most common crop is the potato. The goals of our research were to determine whether potatoes grown on Dravsko polje plain are of sufficient quality (based on nitrate levels) and to examine whether the quality of these potatoes differs from the quality of potatoes cultivated outside Dravsko polje plain. We also aimed to investigate whether the introduction of sustainable agriculture affected the nitrate content of potatoes cultivated in nitrate contaminated groundwater areas. Finally, we examined which varieties of potatoes that are common in northeast Slovenia, have low nitrate accumulation. The results of our research are important for farmers that cultivate potatoes and consumers as well.

\section{Method}

\subsection{Potatoe Samples}

All potato samples were collected from farms after harvest in November 2011, in the time span of two weeks. A total of 57 potato samples were collected: 30 samples from Dravsko polje plain (DP plain), an area with contaminated groundwater, and 27 samples from the vicinity of Pohorje, an area of uncontaminated groundwater (the control region). In total, 28 varieties of potatoes were included in the study. In both areas the following varieties of potatoes were sampled: Bistra, Carlingford, Desiree, Fabiola, Kennebec, Kresnik, Marabel and Romano.

\subsubsection{Sampling Sites}

On DP plain, which has a surface area of $293 \mathrm{~km}^{2}$, samples were collected from areas with different levels of groundwater contamination (measured from 2007 to 2011):

- Siget and Rače, nitrate levels in groundwater were the lowest (25 to $50 \mathrm{mg} / \mathrm{L}$ ),

- Kidričevo and Šikole, nitrate levels were above the permitted limit (50 to $75 \mathrm{mg} / \mathrm{L}$ ),

- Lancova vas and Brunšvik - with the highest nitrate levels in groundwater since they amounted to more than $75 \mathrm{mg} / \mathrm{L}$ (Gacin et al., 2012).

In all three areas, we collected 10 samples of potato from conventional and integrated production systems. There is no organic potato production on DP plain. The area of Lancova vas falls under strict groundwater protection according to Slovenian law UL RS, No. 64/2004 (UL RS, 2004).

In the control region - vicinity of Pohorje, which lies 10 - $40 \mathrm{~km}$ away from DP plain, we collected 27 samples of potatoes from conventional, integrated and organic production systems.

DP plain contains habitats of potatoes grown in gravel and dystric cambisols, while areas surrounding Pohorje contain redzic leptosols and dystric cambisols (Vrščaj, 2005; Food and Agriculture Organization of the United Nations [FAO], 1998). Due to the proximity and similar elevation of the two areas, climatic conditions do not differ significantly. 


\subsubsection{Farm Characteristics}

Table 1. Farm characteristics

\begin{tabular}{cccccccc}
\hline \multirow{2}{*}{ Location } & \multicolumn{3}{c}{$\begin{array}{c}\text { Size of farms } \\
\text { Number } \\
\text { of farms }\end{array}$} & $\begin{array}{c}\text { Number of } \\
\text { samples }\end{array}$ & & $\begin{array}{c}\text { Production systems } \\
\text { Number } \\
\text { of farms }\end{array}$ & $\begin{array}{c}\text { Number of } \\
\text { samples }\end{array}$ \\
\hline $\begin{array}{c}\text { Dravsko polje } \\
\text { plain }\end{array}$ & small & 6 & 10 & conventional & 8 & 14 & without \\
Sedium & 2 & 4 & integrated & 4 & 16 & without \\
SUM & large & 4 & 16 & organic & 0 & 0 & without \\
& & 12 & 30 & & 12 & 30 & \\
Vicinity of & small & 8 & 9 & conventional & 9 & 15 & without \\
Pohorje & medium & 4 & 7 & integrated & 1 & 6 & without \\
SUM & large & 2 & 11 & organic & 5 & 6 & without \\
\hline
\end{tabular}

Potato samples were collected from large farms (arable land planted with potatoes larger than 5 ha), medium-sized farms (arable land planted with potatoes in the range from 1 ha to $5 \mathrm{ha}$ ) and small farms (arable land planted with potatoes is less than $1 \mathrm{ha}$ ) (Table 1). None of the farms practiced irrigation or watering of potatoes.

Integrated production systems [IPS] were established according to Slovenian law UL RS 63/2002 (UL RS, 2002). IPS was set up at a national scale due to the demands provided by Good Agricultural Practice for Protection of Waters [GAP] 2000 for more environmentally friendly activities of sustainable agriculture (Bavec et al., 2009). Organic potato samples were produced according to regulation EC No. 834/2007 (EC, 2007) and UL RS 21/2007 (UL RS, 2007). In order to avoid disturbing the normal process of potato production, farmers were included in the study just before harvest began.

\subsection{Sample Preparation}

Randomized primary samples (approx. $10 \mathrm{~kg}$ of each particular variety) were collected from each plot. Samples were carefully inspected and any damaged or green tubers were discarded. Based on individual weight the primary samples were further divided into smaller sub-samples $(2 \mathrm{~kg})$. The size distribution of individual tubers within each subsample was carefully adjusted to reflect the primary sample (according Hajslová, Schulzová, Slanina, Janné, Hellenäs, \& Andersson, 2005). The sub-samples were stored for maximum 7 days in a refrigerator at $4{ }^{\circ} \mathrm{C}$. The tubers from each sub-sample were washed in tap water, quartered with a stainless knife and peeled. The homogenate prepared from pooled quarters (one quarter from each tuber) was divided into $100 \mathrm{~g}$ aliquots and were immediately frozen and stored at $-25^{\circ} \mathrm{C}$ (up to a maximum of six weeks) until samples were prepared for nitrate content analysis.

Ten grams of the frozen sample were homogenized in $90 \mathrm{~mL}$ of distilled water. $10 \mathrm{~mL}$ of the final suspension was transferred into a $100 \mathrm{~mL}$ flask to which $40 \mathrm{~mL}$ of distilled water was added. The flask was then placed into a water bath for 15 minutes at $70{ }^{\circ} \mathrm{C}$, cooled to room temperature and diluted to a final volume of $100 \mathrm{~mL}$ with deionized water (according to Association of Official Analytical Chemists [AOAC], 1995). The suspension was filtered through Whatman No. 40, of which the first $20 \mathrm{~mL}$ were discarded, and the filtrate was further centrifuged at $15.000 \mathrm{~g}$ for 10 minutes at $4{ }^{\circ} \mathrm{C}$. The extract was kept at $4{ }^{\circ} \mathrm{C}$ until it was analysed by HPLC on the same day.

\subsection{Nitrate Analysis}

Nitrate content was determined by HPLC according to Cheng and Tsang (1998), using a Waters System (Waters Corporation, Milford, MA) controller equipped with Waters 1525 HPLC Pump, Waters 2707 Autosampler and Waters 2998 Photodiode Array detector. Separation was performed on a reversed-phase column (Symmetry C18, $4.6 \times 150 \mathrm{~mm}, 3.5 \mu \mathrm{m}$, Waters). Isocratic separation was used with a mobile phase of $0.010 \mathrm{M}$ octylamine orthophosphate at flow rate $0.5 \mathrm{~mL} / \mathrm{min}$. Nitrate was detected at $213 \mathrm{~nm}$. The injection volume was $10 \mu \mathrm{L}$. Peak 
identification, retention time and peak area integration measurements were performed using HPLC chromatographic data processing software. All reagents were of analytical grade and were prepared in accordance with the manufacturer's procedure. Deionised ultra-clean water was used (Elix 10 Water Purification system; Merck Millipore Headquarters, Billerica, MA). Nitrate stock solution was prepared to final concentrations of $0.5,1.0,2.5,5.0,10.0,25.0$ and $50.0 \mu \mathrm{g} / \mathrm{mL}$ with deionised water. Samples were analysed in duplicate and nitrate content was expressed in $\mathrm{mg}$ nitrate ion $/ \mathrm{kg}$ fresh weight.

\subsubsection{Method Quality Assurance}

From the validation report appropriate linearity $\left(\mathrm{R}^{2}>0.999\right)$ was achieved, repeatability (precision as RSD \%) of the method was $1.07 \%$, the recovery $75-112 \%$, limit of detection [LOD] $5 \mathrm{mg} \mathrm{NO} / \mathrm{kg}$ mass fraction and limit of quantitation [LOQ] $17 \mathrm{mg} \mathrm{NO}_{3} / \mathrm{kg}$ mass fraction. Horrat value was $<2$. Method performance showed that the method complies with the requirements of the Commission Regulation (EC) No. 1882/06 2006 (EC, 2006).

\subsubsection{Statistics}

Microsoft Office Excel 2007 (Microsoft Corporation, Redmond, WA) was used to calculate all statistical parameters. Mann-Whitney $U$ test was used to determine whether there were any significant differences $(\mathrm{p}<$ 0.05 ) between the mean values of the various potatoes' origins.

\section{Results and Discussion}

\subsection{Nitrate Content in Potatoes Sampled From Dravsko Polje Plain}

Nitrate content in potato samples cultivated on DP plain ranged from 18 to $429 \mathrm{mg} / \mathrm{kg}$ with an average value of $157 \mathrm{mg} / \mathrm{kg}$. Six potato samples (20\%) exceeded the maximum recommended level [MRL] of nitrate $-200 \mathrm{mg} / \mathrm{kg}$, of which 4 samples had a nitrate content that surpassed $300 \mathrm{mg} / \mathrm{kg}$. Nitrate content in potato samples of integrated [IPS] and conventional production [CPS] was not statistically significantly different $(p=0.618)$. In both types of production, three samples exceeded the maximum recommended value of $200 \mathrm{mg} / \mathrm{kg}$ (Table 2).

Table 2. Statistical analysis of nitrate content $(\mathrm{mg} / \mathrm{kg}$ fresh weight) in potato samples from Dravsko polje plain

\begin{tabular}{llll}
\hline Statistical parameters & All samples & Integrated cultivation & Conventional cultivation \\
\hline Mean $(\mathrm{mg} / \mathrm{kg})$ & 157 & $146^{\mathrm{a}}$ & $170^{\mathrm{a}}$ \\
Range $(\mathrm{mg} / \mathrm{kg})$ & $18-429$ & $18-429$ & $49-408$ \\
$\mathrm{SD}(\mathrm{mg} / \mathrm{kg})$ & 103 & 96 & 112 \\
$\mathrm{CV}(\%)$ & 65 & 66 & 66 \\
$\mathrm{~N}$ & 30 & 16 & 14
\end{tabular}

$\mathrm{SD}$, standard deviation; $\mathrm{CV}$, coefficient of variation; $\mathrm{N}$, number of samples. Means with the same superscript (a) are not significantly different $(\mathrm{p}>0.05)$.

\subsubsection{Nitrate Contaminated Groundwater and Nitrate Levels in Potatoes}

The influence of nitrate contaminated groundwater on nitrate levels in potatoes can only be indirect - through irrigation. On DP plain, potatoes are not irrigated with nitrate polluted groundwater, thus, due to the shallow roots of the potato, this will not affect nitrate levels. Rather than determining the effect of nitrate polluted groundwater on nitrate levels in potatoes, it is more reasonable to explore the long-term impact of introducing sustainable agriculture, which aims at protecting the groundwater, on the quality of potatoes. 


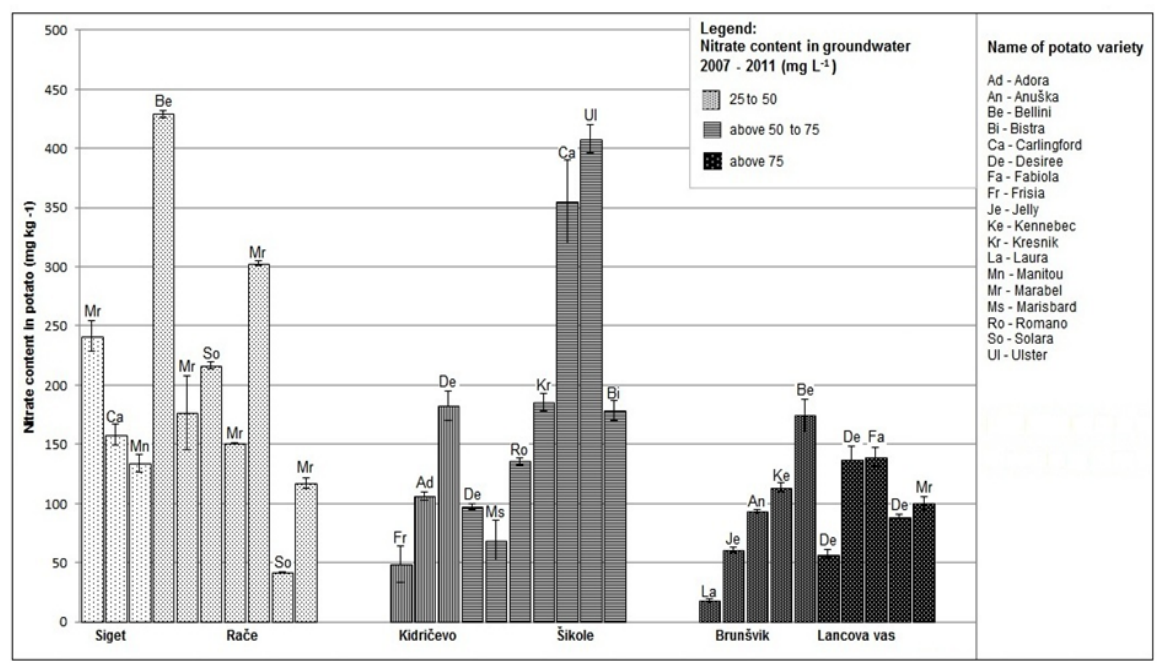

Figure 1. Nitrate contaminated groundwater and nitrate levels in potatoes (shown are mean values of two measurements with biases)

As shown in Figure 1, in the area of Siget and Rače, where the groundwater has the lowest nitrate concentration on DP plain (from 25 to $50 \mathrm{mg} / \mathrm{L}$ ), the number of samples exceeding the MRL ( $200 \mathrm{mg} / \mathrm{kg}$ ) of nitrate content was the highest (4 samples). The average nitrate content in samples of potato was $197 \mathrm{mg} / \mathrm{kg}$ (ranging from 41 to $429 \mathrm{mg} / \mathrm{kg}$ ). Potato samples collected from areas within the DP plain in which groundwater measurements indicate heavy nitrate pollution year after year (from 50 to $75 \mathrm{mg} / \mathrm{L}$ ) had average nitrate levels of $177 \mathrm{mg} / \mathrm{kg}$ (ranging from 49 to $408 \mathrm{mg} / \mathrm{kg}$ ). MRL of nitrate concentration was exceeded in 2 samples. The nitrate content of potatoes grown in Brunšvik and Lancova vas, where groundwater measurements consistently exceed the MCL (even above $75 \mathrm{mg} / \mathrm{L}$ ), is in fact the lowest - ranging from 57 to $174 \mathrm{mg} / \mathrm{kg}$. The area of Lancova vas is defined as water protected area. Low levels of nitrates in potato can be explained by strict adherence to the rules set by the water protection area law. Potatoes collected in Brunšvik were grown outside the water protected area, but on the farm with consistent integrated production systems. The use of nitrogen fertilizers and the intensity of the light are the major factors that influence nitrate content in vegetables (Santamaria, 2006), therefore strict following of GAP, by lowering the use of nitrogen fertilizers, results in lower nitrate accumulation in vegetables. Introduction of water protected areas in order to protect the groundwater reflects in better quality of potato, regarding nitrate content, as well.

\subsection{Nitrate Content in Potatoes Sampled From the Vicinity of Pohorje}

Control samples of potato were collected outside the DP plain in a region that lies in the vicinity of Pohorje. We compared the nitrate content of 27 samples of potatoes that were cultivated at 14 different farms: 15 samples were collected from CPS, 6 samples from IPS, and 6 samples from organic production [OPS].

Table 3. Statistical analysis of nitrate content ( $\mathrm{mg} / \mathrm{kg}$ fresh weight) in potato samples from the vicinity of Pohorje

\begin{tabular}{lllll}
\hline Statistical parameters & All samples & $\begin{array}{l}\text { Integrated } \\
\text { cultivation }\end{array}$ & $\begin{array}{l}\text { Conventional } \\
\text { cultivation }\end{array}$ & $\begin{array}{l}\text { Organic } \\
\text { cultivation }\end{array}$ \\
\hline Mean $(\mathrm{mg} / \mathrm{kg})$ & 126 & $139^{\mathrm{a}}$ & $148^{\mathrm{a}}$ & $58^{\mathrm{b}}$ \\
Range $(\mathrm{mg} / \mathrm{kg})$ & $14-448$ & $42-348$ & $28-448$ & $14-156$ \\
$\mathrm{SD}(\mathrm{mg} / \mathrm{kg})$ & 104 & 113 & 110 & 51 \\
$\mathrm{CV}(\%)$ & 83 & 81 & 74 & 87 \\
$\mathrm{~N}$ & 27 & 6 & 15 & 6 \\
\hline
\end{tabular}

$\mathrm{SD}$, standard deviation; $\mathrm{CV}$, coefficient of variation; $\mathrm{N}$, number of samples. Means with the same superscript (a) are not significantly different $(\mathrm{p}>0.05)$. 
Nitrate content in all potato samples from the vicinity of Pohorje had a mean value $126 \mathrm{mg} / \mathrm{kg}$ (ranging from 14 to $448 \mathrm{mg} / \mathrm{kg})$. As the area of DP plain, this area also did not show statistically significant difference $(\mathrm{p}=0.425)$ in nitrate content between the samples of CPS and IPS. OPS samples, with the mean value of nitrates $58 \mathrm{mg} / \mathrm{kg}$, had statistically significant lower nitrat content than the CPS and IPS potato samples $(p=0.009$ and 0.046 respectively) (Table 3). The literature states the opposite; some report about lower measured nitrate contents in OPS potato samples (Hajslová et al., 2005), the others report that OPS does not influence the nitrate content (Lachman et al., 2005; Zarzecka, Gugała, \& Mystkowska, 2010). Our study confirms the significant impact on lower nitrate content in potato by OPS, but also not by IPS.

\subsection{Comparison Between Both Areas}

The amount of nitrate in tubers depends on a number of factors: cultivar variety, maturity of the tubers and their size and type, amount of nitrogen fertilizer, growing region, site and years of cultivation. Furthermore, different climatic conditions, mainly light and temperature, but also weather and storage conditions, can also affect nitrate content (Bélanger, Walsh, Richards, Milburn, \& Ziadi, 2002; Hajslová et al., 2005; Ierna, 2009; Lachman, Hamouz, Dvořák, \& Orsák, 2005; Rogozinska, Pawelzik, Poberezny, \& Delgado, 2005). DP plain and the vicinity of Pohorje are characterized by similar soils and climate. In both regions, potatoes were sampled during the same time period and the samples were handled in the same way, thus we can assume that any significant differences that may arise in nitrate content between the two areas can be explained by two factors: differences in production of potatoes and potato variety. There were no significant differences $(p=0.503)$ between nitrate levels in all potatoes sampled from Dravsko polje plain and from the control region - in other words, the quality of the potato from Dravsko polje plain characterized by contaminated groundwater and intensive farming does not differ significantly from the quality of the potato, regarding the nitrate content, grown outside this area.

In all of our potato samples (DP plain and the vicinity of Pohorje) nitrate levels ranged from 14 to $448 \mathrm{mg} / \mathrm{kg}$ with a mean value of $143 \mathrm{mg} / \mathrm{kg}$. The MRL of nitrate concentration $(200 \mathrm{mg} / \mathrm{kg})$ was greatly surpassed in $18 \%$ of all analysed samples. Our results are in accordance to the six-year report on nitrate levels in vegetables grown in Slovenia (Sušin, Kmecl, \& Gregorčič, 2006), which reported that in 202 analysed samples of potato the average nitrate content was $158 \mathrm{mg} / \mathrm{kg}$ (ranging from 2 to $704 \mathrm{mg} / \mathrm{kg}$ ), of which $16 \%$ of the samples exceeded the MRL. However, above mentioned study reported higher maximum nitrate concentrations.

Our findings on nitrate levels in potato samples are also comparable to the nitrate levels reported by Cieślik, 1995 and Rogozinska et al., 2005. On the other hand, nitrate levels in potato samples reported in this study were higher than the maximum values reported by other researchers such as Ierna (2009), Lachman et al. (2005), and Zarzecka et al. (2010).

\subsection{Potato Varieties and Nitrate Content}

Potato variety and type of the production system had a major impact on the nitrate content in our potato samples. Table 4 shows the nitrate content of each potato variety, produced by different productions systems, in two different areas with the same climate conditions. 
Table 4. Varieties of potatoes, production systems and nitrate content $(\mathrm{mg} / \mathrm{kg})$ in potatoes sampled from Dravsko polje plain with groundwater nitrate contamination and nitrate uncontaminated vicinity of Pohorje

\begin{tabular}{|c|c|c|c|c|c|c|}
\hline \multicolumn{4}{|c|}{ Dravsko polje plain } & \multicolumn{3}{|c|}{ Vicinity of Pohorje } \\
\hline \multirow[t]{2}{*}{$\begin{array}{l}\text { Varieties with } \\
\text { sample ID }\end{array}$} & \multirow[t]{2}{*}{$\begin{array}{l}\text { Product. } \\
\text { systems }\end{array}$} & \multirow{2}{*}{$\begin{array}{l}\text { Areas of } \\
\text { groundwater } \\
\text { contaminat. }\end{array}$} & $\begin{array}{l}\text { Nitrate content } \\
\text { (mg/kg f.w.) }\end{array}$ & \multirow[t]{2}{*}{$\begin{array}{l}\text { Varieties with } \\
\text { sample ID }\end{array}$} & \multirow[t]{2}{*}{$\begin{array}{l}\text { Product. } \\
\text { systems }\end{array}$} & \multirow{2}{*}{$\begin{array}{l}\text { Nitrate content } \\
\text { (mg/kg f.w.) } \\
\text { Mean } \pm \text { SD }\end{array}$} \\
\hline & & & Mean \pm SD & & & \\
\hline 01-Marabel & IPS & Siget & $241 \pm 6,7$ & 31-Marabel & IPS & $113 \pm 0.3$ \\
\hline 14-Marabel & CPS & Lancova vas* & $101 \pm 2,9$ & 37-Marabel & CPS & $142 \pm 4.5$ \\
\hline 21-Marabel & IPS & Rače & $177 \pm 15,7$ & 45-Marabe & CPS & $53 \pm 1.8$ \\
\hline 26-Marabel & CPS & Rače & $151 \pm 0,1$ & 57-Marabel & OPS & $48 \pm 1.2$ \\
\hline 27-Marabel & CPS & Rače & $303 \pm 0,9$ & 39-Desiree & CPS & $83 \pm 3.8$ \\
\hline 30-Marabel & IPS & Rače & $117 \pm 2,2$ & 48-Desiree & CPS & $165 \pm 1.6$ \\
\hline 04-Desiree & CPS & Lancova vas* & $57 \pm 1,7$ & 56-Desiree & OPS & $30 \pm 1.0$ \\
\hline 07-Desiree & CPS & Kidričevo & $183 \pm 6,2$ & 49-Romano & CPS & $201 \pm 0.6$ \\
\hline 08-Desiree & CPS & Šikole & $97 \pm 1,3$ & 50-Romano & CPS & $175 \pm 3.0$ \\
\hline 11-Desiree & IPS & Lancova vas* & $137 \pm 5,3$ & 52-Romano & OPS & $36 \pm 1.2$ \\
\hline 13-Desiree & IPS & Lancova vas* & $88 \pm 1,5$ & 38-Kresnik & CPS & $62 \pm 0.7$ \\
\hline 02-Carlingford & IPS & Siget & $158 \pm 4,5$ & 44-Kresnik & CPS & $88 \pm 18.6$ \\
\hline 16-Carlingford & CPS & Šikole & $355 \pm 17,5$ & 47-Carlingford & CPS & $448 \pm 6.0$ \\
\hline 19-Bellini & IPS & Rače & $429 \pm 1,5$ & 32-Fabiola & IPS & $94 \pm 4.0$ \\
\hline 28-Bellini & IPS & Brunšvik & $174 \pm 6,9$ & 33-Savanna & IPS & $42 \pm 0.2$ \\
\hline 23-Solara & IPS & Rače & $217 \pm 1,6$ & 34-Sora & IPS & $348 \pm 10.7$ \\
\hline 29-Solara & IPS & Rače & $41 \pm 0,3$ & 35-Elfe & IPS & $59 \pm 2.2$ \\
\hline 03-Manitou & IPS & Siget & $134 \pm 3,8$ & 36-Gala & IPS & $175 \pm 5.7$ \\
\hline 05-Frisia & CPS & Kidričevo & $49 \pm 7,6$ & 40-Bistra & CPS & $28 \pm 4.6$ \\
\hline 06-Adora & CPS & Kidričevo & $106 \pm 1,6$ & 41-Primura & CPS & $69 \pm 1.8$ \\
\hline 09-Marisbard & CPS & Šikole & $69 \pm 8,5$ & 46-Primura & CPS & $171 \pm 1.3$ \\
\hline 10-Romano & CPS & Šikole & $136 \pm 1,5$ & 42-Kennebec & CPS & $184 \pm 6.4$ \\
\hline 12-Fabiola & IPS & Lancova vas* & $139 \pm 3,8$ & 43-Virgo & CPS & $297 \pm 0.6$ \\
\hline 15-Kresnik & CPS & Šikole & $186 \pm 3,6$ & 51-Riviera & CPS & $60 \pm 1.5$ \\
\hline 17-Ulster & CPS & Šikole & $408 \pm 6,1$ & 53-Raja & OPS & $67 \pm 3.2$ \\
\hline 18-Bistra & CPS & Šikole & $179 \pm 4,4$ & 54-Agria & OPS & $14 \pm 0.6$ \\
\hline 20-Laura & IPS & Brunšvik & $18 \pm 0,7$ & 55-Sante & OPS & $156 \pm 1.6$ \\
\hline 22-Jelly & IPS & Brunšvik & $61 \pm 1,4$ & & & \\
\hline 24-Anuška & IPS & Brunšvik & $93 \pm 0,8$ & & & \\
\hline 25-Kennebec & IPS & Brunšvik & $113 \pm 1,9$ & & & \\
\hline
\end{tabular}

Note: Shown are mean values of two measurements within \pm SD.

IPS, integrated production systems; CPS, conventional production systems; OPS, organic production systems;

* indicate water protected area.

The most common potato varieties on DP plain and vicinity of Pohorje are Marabel and Desiree (Table 4). Nitrate content in variety Marabel in the area of DP was ranging from 101 (grown by CPS) to $303 \mathrm{mg} / \mathrm{kg}$ (CPS), whereas in samples from vicinity of Pohorje from 48 (OPS) to $142 \mathrm{mg} / \mathrm{kg}$ (CPS). Nitrate content exceeded MRL in two samples. Nitrate content in variety Desiree ranged from 57 (CPS) to $183 \mathrm{mg} / \mathrm{kg}$ (CPS) on DP and in the 
vicinity of Pohorje from 30 (OPS) to $165 \mathrm{mg} / \mathrm{kg}$ (CPS). MRL was not exceeded in any of the Desiree samples. Among the potato samples with the highest content of nitrate (above the MRL) were, on DP, varieties: Bellini (IPS), Ulster (CPS), Carlingford (CPS) and samples Marabel of different productions systems (CPS and IPS). In the vicinity of Pohorje the potato varieties exceeding the MRL were Carlingford (CPS), Sora (IPS), Virgo (CPS) and Romano (CPS). Between samples with excessive nitrates there are also samples of IPS; these results indicate that the principles of good agriculture practice (GAP) were not followed consistently among the farms. Carlingford samples exceeded the MRL in both areas, which may also indicate a tendency of increased nitrate accumulation in this potato variety. Low levels of nitrate $(<50 \mathrm{mg} / \mathrm{kg})$ were measured in DP potato varieties: Laura (IPS), Solara (IPS) and Frisia (CPS); in the vicinity of Pohorje the varieties with the low nitrate contents were: Agria (OPS), Bistra (CPS), Desiree (OPS), Romano (OPS) and Marabel (OPS). Among the samples of potato containing the minimum nitrate levels were frequently those from organic production. Comparison of varieties with the lowest and the highest nitrate content showed that samples of Marabel variety were found at both extremes. Overall it can be concluded, that the type of production has a greater influence on the nitrate content than the potato variety. However, the tendency for nitrate accumulation in individual varieties (e.g. variety Carlingford with high and variety Desiree with low nitrate accumulation), which is in accordance with the reportings (Cieślik \& Sikora, 1998; Hajslová et al., 2005; Lachman et al., 2005 ; Ierna, 2009), should be further explored on a larger number of samples and considered when planning the reduction of nitrate intake with food.

\section{Conclusions}

Nitrate levels in potatoes cultivated in Dravsko polje plain with nitrate contaminated groundwater were not significantly different from the nitrate levels in potatoes cultivated outside this contaminated area. In both areas, nitrate levels in samples of potato greatly exceeded the maximum recommended level. Contaminated groundwater does not influence on nitrate content in potatoes, whereas strict legislation with introducing water protected areas in order to protect the groundwater, does. Strict compliance with GAP results in lower nitrate levels in potatoes. The label "integrated production" does not warrant the consumer that potatoes contain lower nitrate content. Nitrate intake can be reduced by consuming organic potatoes and potatoes produced on farms where the principles of sustainable agriculture are strictly adhered to. The latter is difficult to predict without analysing the nitrate content of potatoes. The possibility of nitrate reduction by selecting potatoe varieties with low nitrate accumulation, such as the popular variety Desiree, should not be overlooked. Future research should focus on selection of potato varieties with low nitrate accumulation and further changes in nitrate levels during culinary processing of potato.

\section{References}

AOAC. (Association of Official Analytical Chemists). (1995). Official methods of analysis of the Association of Analytical Chemists (16th ed.). Washington, DC: Association of Official Analytical Chemists.

ARSO. (Slovenian environment agency). (2013). Total monthly precipitation and monthly air temperature in 2011. Ministry of agriculture and environment. Retrieved from http://meteo.arso.gov.si

Bavec, M., Grobelnik, M. S., Rozman, Č., Pažek, K., \& Bavec, F. (2009). Sustainable agriculture based on integrated and organic guidelines: understanding terms. The case of Slovenian development and strategy. Outlook on Agriculture, 38(1), 89-95. http://dx.doi.org/10.5367/000000009787762824

Bélanger, G., Walsh, R., Richards, J. E., Milburn, P. H., \& Ziadi, N. (2002). Nitrogen fertilization and irrigation affects tuber characteristics of two potato cultivars. American Journal of Potato Research, 79, 269-279. http://dx.doi.org/10.1007/BF02986360

Cheng, C. F., \& Tsang, C. W. (1998). Simultaneous determination of nitrite, nitrate and ascorbic acid in canned vegetable juices by reverse-phase ion-interaction HPLC. Food Additives and Contaminants, 15(7), 753-758. http://dx.doi.org/10.1080/02652039809374706

Cieślik, E. (1995). The effect of weather conditions on the level of nitrates in tubers of some potato varieties. Polish Journal of Food And Nutrition Sciences, 4(45), 11-19.

Cieślik, E., \& Sikora, E. (1998). Correlation between the levels of nitrates and nitrites and the contents of potassium, calcium and magnesium in potato tubers. Food Chemistry, 63, 525-528. http://dx.doi.org/10.1016/S0308-8146(98)00027-2

Du, S. T., Zhang, Y. S., \& Lin, X. Y. (2007). Accumulation of nitrate in vegetables and its possible implications to human health. Agricultural Science in China, 6(10), 1246-1255. http://dx.doi.org/10.1016/S1671-2927(07)60169-2 
EC (European Commission). (2006). Regulation 1882/06. Laying down methods of sampling and analysis for the official control of the levels of nitrates in certain foodstuffs. Official Journal of the European Union, $L$ $364 / 25$. Retrieved from http://eurlex.europa.eu/LexUriServ/LexUriServ.do?uri=OJ:L:2006:364:0025:0031:EN:PDF

EC (European Commission). (2007). Regulation No 834/2007 on organic production and labelling of organic products and repealing Regulation (EEC) No 2092/91. Official Journal of the European Union, L 189/1. Retrieved from http://eurlex.europa.eu/LexUriServ/LexUriServ.do?uri=OJ:L:2007:189:0001:0023:EN:PDF

EC (European Commission). (2011). Regulation No 1258/2011: Amending Regulation (EC) No 1881/2006 as regards maximum levels for nitrates in foodstuffs. (2011). Official Journal of the European Union, 320, $15-17$. Retrieved from http://eurlex.europa.eu/LexUriServ/LexUriServ.do?uri=OJ:L:2011:320:0015:0017:EN:PDFEuropean

EPA (Environmental Protection Agency). (2012). Estimated nitrate concentrations in groundwater used for drinking. United States Environmental Protection Agency. Retrieved from http://water.epa.gov

EUROSTAT (European Statistics). (2011). Food: from farm to fork statistics 2011. Publications Office of the $\begin{array}{cc}\text { European } & \text { Union. } \\ \text { http://epp.eurostat.ec.europa.eu/cache/ITY_OFFPUB/KS-32-11-743/EN/KS-32-11-743-EN.PDF }\end{array}$

FAO (Food and Agriculture Organization of the United nations). (1998). World reference base for soil resources - ISSS-ISRIC-FAO. 84 World Soil Resources Reports. Rome.

Gacin, M., Mihorko, P., Dobnikar, T. M., \& Knez, J. (2012). Ocena kemijskega stanja podzemnih voda v Sloveniji v letu 2011. [Chemical status of underground water bodies in 2011]. Ministry of agriculture and environment. Slovenian environment agency. Retrieved from http://www.arso.si

GAP (Good Agricultural Practice for Protection of Waters). (2000). Directive 2000/60/EC of the European Parliament and of the Council establishing a framework for Community action in the field of water policy. Official Journal of the European Communities, L 372/1. Retrieved from http://eur-lex.europa.eu/LexUriServ/LexUriServ.do?uri=OJ:L:2000:327:0001:0072:EN:PDF

Hajšlová, J., Schulzová, V., Slanina, P., Janné, K., Hellenäs, K. E., \& Andersson, C. H. (2005). Quality of organically and conventionally grown potatoes: four-year study of micronutrients, metals, secondary metabolites, enzymic browning and organoleptic properties. Food Additives and Contaminants, 22(6), 514-34. http://dx.doi.org/10.1080/02652030500137827

Hmelak Gorenjak, A., \& Cencič, A. (2013). Nitrate in vegetables and their impact on human health. A review. Acta Alimentaria, 42 (2),158-172. http://dx.doi.org/10.1556/AAlim.42.2013.2.4

Hmelak, G. A., Rižman, K. U., \& Cencič, A. (2012). Nitrate content in dandelion (Taraxacum officinale) and lettuce (Lactuca sativa) from organic and conventional origin: intake assessment. Food Additives and Contaminants, Part B., 5(2), 93-99. http://dx.doi.org/10.1080/19393210.2012.658873

Hord, N. G., Tang, Y., \& Bryan, N. S. (2009). Food sources of nitrates and nitrites: the physiologic context for potential health benefits. The American Journal of Clinical Nutrition, 90(1), 1-10. http://dx.doi.org/10.3945/ajen.2008.27131

Ierna, A. (2009). Influence of harvest date on nitrate contents of three potato varieties for off-season production. Journal of Food Composition and Analysis, 22, 551-555. http://dx.doi.org/10.1016/j.jfca.2008.11.007

Lachman, J., Hamouz, K., Dvoř́k, P., \& Orsák, M. (2005). The effect of selected factors on the content of protein and nitrates in potato tubers. Plant, Soil and Environment, 51(10), 431-438. Retrieved from http://www.agriculturejournals.cz/publicFiles/50997.pdf

Lundberg, J. O., Weitzberg, E., \& Gladwin, M. T. (2008). The nitrate-nitrite-nitric oxide pathway in physiology and therapeutics. Nature Reviews Drug Discovery, 7, 156-167. http://dx.doi.org/10.1038/nrd2466

McKnight, G., Smith, L. M., Drummond, R. S., Duncan, C. W., Goldem, M. N. H., \& Benjamin, N. (1997). The chemical synthesis of nitric oxide in the stomach from dietary nitrate in man. Gut, 40, 211-214. Retrieved from http://www.ncbi.nlm.nih.gov/pmc/articles/PMC1027050/

Rogozinska, I., Pawelzik, E., Poberezny, J., \& Delgado, E. (2005). The effect of different factors on the content of nitrate in some potato varieties. Potato Research, 48, 167-180. http://dx.doi.org/10.1007/BF02742374

Santamaria, P. (2006). Nitrate in vegetables: toxicity, content, intake and EC regulation. Journal of the Science of Food and Agriculture, 86, 10-17. http://dx.doi.org/10.1002/jsfa.2351 
Sobko, T., Marcus, C., Govoni, M., \& Kamiya, S. (2010). Dietary nitrate in Japanese traditional foods lowers diastolic blood pressure in healthy volunteers. Nitric Oxide, 22, 136-140. http://dx.doi.org/10.1016/j.niox.2009.10.007

Speijers, G. J. A. (1996). Nitrite. In: Toxicological Evaluation of Certain Food Additives and Contaminants. World Health Organization Food, International Programme on Chemical Safety (WHO Food Additives Series 35), Geneva.

Sušin, J., Kmecl, V., \& Gregorčič, A. (2006). A survey of nitrate and nitrite content of fruit and vegetables grown in Slowenia during 1996-2002. Food Additives and Contaminants, 23(4), 385-390. http://dx.doi.org/10.1080/02652030600573715

Thomson, B. M., Nokes, C. J., \& Cressey, P. J. (2007). Intake and risk assessment of nitrate and nitrite from New Zealand foods and drinking water. Food Additives and Contaminants, 24(2), 113-121. http://dx.doi.org/10.1080/02652030600934206

UL RS (Official Gazette RS). (2002). Pravilnik o integrirani pridelavi zelenjave. [Rules on integrated vegetable production]. Official Gazette of the Republic of Slovenia, 63/2002. Retrieved from http://www.uradni list.si/1/content?id=37548\#!/Pravilnik-o-integrirani-pridelavi-zelenjave

UL RS (Official Gazette RS). (2004). Pravilnik o kriterijih za določitev vodovarstvenega območja. [Rules on criteria for the designation of a water protection zone]. Official Gazette of the Republic of Slovenia, 64/2004. Retrieved from http://www.uradni-list.si/1/objava.jsp?urlid=200464\&stevilka=2915

UL RS (Official Gazette RS). (2007). Pravilnik o ekološki pridelavi in predelavi kmetijskih pridelkov oziroma živil. [Rules on organic production and processing of agricultural products and/or foods]. Official Gazette of the Republic of Slovenia, 21/2007. Retrieved from http://www.uradni-list.si/1/objava.jsp?urlurid=20071065

UL RS (Official Gazette RS). (2009). Uredba o stanju podzemnih voda. [Decree on groundwater status]. Official Gazette of the Republic of Slovenia, 25/2009. Retrieved from http://www.uradni-list.si/1/objava.jsp?urlid=200925\&stevilka=1058

Vrščaj, B., Prus, T., \& Lobnik, F. (2005). Soil information and soil data use in Slovenia. European soil bureau $\begin{array}{lllll}\text { Research report no. } & 9 . & \text { Retrieved }\end{array}$ http://eusoils.jrc.ec.europa.eu/ESDB_Archive/eusoils_docs/esb_rr/n09_soilresources_of_europe/Slovenia.pdf

Walker, R. (1990). Nitrates, nitrites and N-nitrosocompounds: a review of the occurrence in food and diet and the toxicological implications. Food Additives and Contaminants, 7, 717-768. http://dx.doi.org/10.1080/02652039009373938

Weichselbaum, E. (2010). An overview of the role of potatoes in the UK diet. Nutrition Bulletin, 35, 195-206. http://dx.doi.org/10.1111/j.1467-3010.2010.01845.x

Zarzecka, K., Gugała, M., \& Mystkowska, I. (2010). Herbicide residues and nitrate concentration in tubers of table potatoes. Journal of Toxicology and Environmental Health, Part A, 73, 1244-1249. http://dx.doi.org/10.1080/15287394.2010.492011

\section{Copyrights}

Copyright for this article is retained by the author(s), with first publication rights granted to the journal.

This is an open-access article distributed under the terms and conditions of the Creative Commons Attribution license (http://creativecommons.org/licenses/by/3.0/). 